DOI: $10.17803 / 2313-5395 \cdot 2021 \cdot 3 \cdot 17 \cdot 453-471$

\title{
"Architecture" of Civil Registration: Text and Digital Format
}

\author{
Irina A. Trofimets \\ Embassy of the Russian Federation \\ in the Kingdom of Spain, Madrid, Spain
}

\begin{abstract}
The author has attempted to show that in the context of building information society the format of its management changes, and law is being transformed accordingly as the main social regulator. Traditional state institutions are being modernized including the sector of registry office. The civil status record as the "primary cell" of the Unified State Register has been transformed from a simple text into an electronic one. The organizational and legal basis for the change in the format of the civil status act was a whole block of normative legal acts of various legal force. At the same time, the adoption of methodological and technical standards is required, without which it is impossible to form the maintenance of act records in a new digital format. We consider the need for the modernization of the entire system of state registration of civil status acts to update the legal terminology used in the field of legal regulation of relations in the field of civil registration. Many terms from everyday life become legal categories in information law, and need official and doctrinal interpretation ("digital landscape," "digital hygiene", etc.). It is for this reason that the conceptual legal apparatus is objectively subject to renewal. In this article, the author substantiates the advisability of applying the term architecture to a civil registration in digital format.
\end{abstract}

Keywords: Unified State Register of Acts of Civil Status; architecture of civil status act recording; digital format; text format; information security; legal and technical measures

Cite as: Trofimets, I.A., (2021). "Architecture" of Civil Registration: Text and Digital Format. Kutafin Law Review, 8(3), pp. 453-471, doi: 10.17803/2313-5395.2021.3.17.453-471. 


\section{Contents}

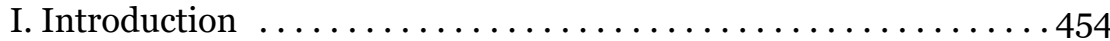

II. Digitalization and the Sphere of Civil Registry:

Conceptual Apparatus ........................... 455

III. History of the Civil Registry . . . . . . . . . . . . . . . 458

IV. "State Registration of the Act of Civil Status" and "Record of the Act of Civil Status" ................. . 461

V. Categories "Form" and "Architecture" .................. 462

VI. Types of Civil Status Acts......................... 465

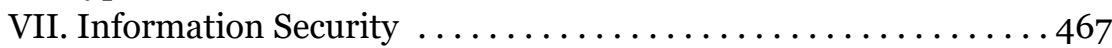

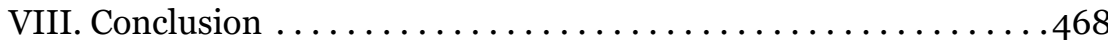

References..................................469

\section{Introduction}

The challenges of the 21st century associated with the transition from an industrial society to a global information society, ${ }^{1}$ the introduction of digital technologies and platform modules require solutions in many areas including various fields of administration and rendering of public services in order to ensure optimal interaction between the state and civil society in the new reality within the legal framework.

Electronic (digital) management "penetrates" into all areas of public life, the sector of state registration of civil status acts is no exception. Historically, civil status is recorded in order to account the population, confirm the existence of an individual and his legal capacity (Breckenridge and Szreter, 2014). The construction of "acts of civil status," developed by western clergy (Gordon, 2018) in the Middle Ages to record information about the most important biographical and demographic events of a person's life (birth, ${ }^{2}$ marriage and death), "took root" and showed its effectiveness. (August).

${ }^{1}$ Okinawa Charter on Global Information Society (2000). Diplomatic Herald.

${ }^{2}$ About the importance of birth registration: Hunter, W. and Brill, R., (2016). "Documents, Please" Advances in Social Protection and Birth Certification in the Developing World. World Politics, 68(2), pp. 191-228, doi: 10.1017/ So043887115000465. Available at: https://www.cambridge.org/core/journals/ world-politics/article/abs/documents-please/8522DA3AF8F1EDB207444F482 
During its two-century history the Russian institute of civil status acts has gone through serious metamorphoses: from the birth registers in parishes to the registry office information system. Currently the Unified State Register of Civil Status Acts exists in electronic format and is based on an extraterritorial principle.

\section{Digitalization and the Sphere of Civil Registry: Conceptual Apparatus}

Digitalization in the sphere of civil registry offices requires a revision of the conceptual apparatus and the determination of new legal categories such as: "digital format," "electronic format," "electronic resource," "information resource," "information system," "telematics network," "telecommunications network," "electronic document," "electronic document management," "electronic signature," "digital signature," "electronic digital signature," "reinforced qualified electronic signature," "form of civil registration," "architecture of civil status act recording," etc., which reflect the process of fundamental transformation of the institute of the state registration of civil status acts. Indeed, many terms have already been legally defined, for example, in the Federal Law No 149-FZ dated July 27, 2006, "On Information, Information Technologies and the Protection of Information," 3 Federal Law No 152-FZ dated July 27, 2006, "On Personal Data,"4 etc. However, some terms are yet to be officially defined, which leads to not only discussions among law theorists, but also complicates law enforcement practice.

In the opinion of T.Ya. Khabrieva and N.N. Chernogor, "one of the directions of scientific research is the doctrinal development of new phenomena and processes that have arisen and are taking place in the state legal sphere under the influence of the digitalization of the economy,

9656F4E [Accessed 21.05.2021]; Szreter, S., (2007). The Right of Registration: Development, Identity Registration, and Social Security - A Historical Perspective. World Development, 35(1), pp. 67-86, doi: 10.1016/j.worlddev.2006.09.004.

3 Federal Law No 149-FZ dated July 27, 2006, "On information, information technologies and the protection of information" (current version). Collection of Legislation of the Russian Federation (31.07.2006), No 31 (part I), Art. 3448 (In Russ.).

4 Federal Law No 152-FZ dated July 27, 2006, “On Personal Data.” Collection of Legislation of the Russian Federation (31.07.2006), No 31 (part I), Art. 3451 (In Russ.). 
management and law" (Khabrieva and Chernogor, 2018, p. 87). At the same time scholars claim that "the law retains its substantial features, is not subject to significant transformations under the influence of the "digitization" of public life, in a regular mode reacts to the changes taking place, continuing to perform its functions" (Khabrieva and Chernogor, 2018, pp. 87-88). We believe that this conclusion is controversial since public relations of a new digital format require new legal regulations; in particular, it is necessary to update the conceptual apparatus at the legislative level. The role of law in society remains the same: regulation of relations, but modernization of this social regulator is required since new phenomena of public life should be subject only to adequate legal influence. "Outdated" legal constructions and techniques that do not correspond to realities objectively "die off" and "dead" norms cannot operate. Each time has its own rules.

E.E. Antonova (Antonova, 2012), Yu.M. Baturin (Baturin, 1991), O.A. Boyarintseva (Boyarintseva, 2019), A.A. Chebotareva (Chebotareva, 2014), N.N. Chernogor (Khabrieva and Chernogor, 2018), D.V. Ivanov (Ivanov, 2012), G.G. Kamalova (Kamalova, 2020), V.A. Kopylov (Kopylov, 1998), T.Ya. Khabrieva (Khabrieva, 2017), A.V. Minbaleev (Minbaleev, 2006; 2012), T.A. Polyakova (Polyakova, 2020), D.D. Savenkova (Savenkova, 2019), L.K. Tereshchenko (Tereshchenko, 2011), A.B. Vengerov (Vengerov, 1978), V.A. Zhilkin (Zhilkin, 2018) and others addressed the general problems of modern legal terminology in the realm of digital transformation. Thus, V.A. Zhilkin writes about the need for "scientific approaches to the development of a new generation of regulatory framework in order to ensure digital transformation" and the search for "flexible legal regulators in the field of digitalization in the virtual space" (Zhilkin, 2018, p. 74).

In order to preserve conceptual continuity, some terms (for example, "electronic signature," "digital signature" and "electronic digital signature") are used synonymously. Since the categories "digital format" and "electronic format" are often understood as similar ones, we consider it necessary to make a reservation that, based on wellestablished ideas in the field of high technologies, they can really be used as synonymous words or still be used in different meanings, it all depends on the aspect of application. So, if the information is stored in 
the computer memory (digital format), then it is called information in electronic format, despite the fact that it is reproduced for perception in the form of text - an electronic document. ${ }^{5}$

The novelty of the legislation is the provision of remote application for the Registry Office service. The Registry Office service in electronic form is provided only for citizens authorized on the Unified Portal of State and Municipal Services. The identification and authentication of the applicant is carried out remotely. We believe that this public service in electronic form, despite its advantages, will not soon be generally accessible. Not every Russian household has a computer and the Internet. Many Russians fail to have basic digital skills and just a small part of the population in Russia has professional level in this field. ${ }^{6}$ V.B. Naumov addresses this issue in his scientific works, noting that there is "the growing 'digital divide' ('digital inequality') in society, when billions of people may be left behind the abuilding civilization" (Naumov, 2018, p. 4; Naumov, 2020, p. 77). With regard to the ongoing changes, the state registration of civil status acts remains a traditional institution in the legal system of the state. S.M. Korneev wrote "what it means to answer the question about the civil status of a citizen - it means to indicate the facts that individualize him (last name, first name, patronymic, citizenship, gender, age)... and marital status" (Korneev, 2008, p. 166). The purpose of this institution is to individualize citizens by securing their specific legal status.

5 The lawmaker has repeatedly tried to give a legal definition to an electronic document in regulatory legal and other official acts. See, for example, paragraph 11.1 of the article 2 of the Federal Law No 149-FZ dated July 27, 2006, "On information, information technologies and the protection of information" (In Russ.); paragraph 1 of the Resolution of the Plenum of the Supreme Court of the Russian Federation No 57 dated December 26, 2017, "On certain issues of the application of legislation regulating the use of documents in electronic form in the activities of courts of general jurisdiction and arbitration courts" (In Russ.); paragraph 1.6.1 of the Regulations of the Certification Center of the Eurasian Economic Commission (Decision of the Board of the Eurasian Economic Commission No 110 dated July 9, 2018).

${ }^{6}$ According to Higher School of Economics estimates, only $12 \%$ of adults (15 years and older) in Russia have developed digital skills above the basic level. At the same time, on average, in 28 EU countries, a third of the adult population shows a similar level. In the Netherlands, Finland, the UK and Denmark, this figure reaches almost 50 \%. Available at: https://www.cnews.ru/news/top/2020-07-09_rossiyane_ razgromno_ustupili [Accessed 11.02 2021] (In Russ.). 


\section{History of the Civil Registry}

The original name of the category in question was "general acts of the status," which was changed in 1910 by the highly established editorial commission in the preparation of the draft Civil Code for the modern "acts of civil status" as more appropriate, certifying the beginning (birth) and end (death) of the existence of a person (citizen) as a subject of legal relations and "his belonging to a certain family and genus." General acts of status were also used because historically Orthodox parishes were obliged to keep metric books of the population, regardless of the classes of parishioners, and for the reason that the political and legal status of persons in Tsarist Russia was defined as citizenship, the term "citizenship" appeared later than the introduction of metric records.

The modern institution of civil status acts in the domestic legal system, in comparison with another jurisdictional structure - the notary public, can be considered "young." Indeed, the rudimentary institution of civil status acts owes its appearance in Russia to the personality of Peter I, who positively assessed the clerical activities of Western priests to record certain important events in people's lives (birth (baptism), marriage (wedding) and death (funerals), the regulation of which was provided for by canonical norms and was carried out, as a rule, for remuneration. On a permanent and mandatory basis, the maintenance of metric books in Russia was provided for in 1724 by the Synod Decree "On the maintenance by priests of metric books for recording births, marriages and deaths, on sending from them extracts to the Bishops annually." Metric books are demographic documents of important biographical facts (births, marriages, deaths) that were recorded in chronological order during a calendar year.

The main goal pursued by the clergy was to firmly attach the population to a certain area. G.F. Shershenevich wrote "a person married and died where he was born, where his parents and relatives married and died" (Shershenevich, 1995, p. 66). As time passed, the political interests of the church came into conflict with the interests

7 Complete collection of legislation of the Russian Empire. SPb., Type II Branch of His Imperial Majesty's Own Chancellery (1830). Vol. I. T. VII. P. 266 (In Russ.). 
of the state, and church jurisdiction became limited. The state realized the effectiveness of actions to register individual status of individuals, and since there was no structure in the state apparatus to assign the corresponding functions, the records of births, baptisms, weddings and burials remained in the jurisdiction of the priests, but now on a mandatory basis and with the payment of part of the received contributions to the treasury. Thus, the state not only kept some kind of accounting of the population, but also, without spending money on the maintenance of officials, had a stable source of income in its budget.

Freedom of religion in the West has made it difficult to keep records of a person's status. Representatives of other faiths (not Catholics) refused to register in Catholic parishes. The most progressive states secularized the records of births, marriages, and deaths, forming a staff of officials to whom these functions were assigned. Earlier than all the registration of the designated legal facts from the church to the state jurisdiction was transferred in France (1792) and in Germany (1874).

Russia followed a different path: the church was annexed to the state. In Tsarist Russia it was forbidden to be an atheist and not to belong to any religion, i.e. "to be in a non-religious status." It is noted that since the adoption of foreign regulations on the registration of the facts of birth, marriage and death, no special institution was created, and the testimony was carried out by the clergy in Orthodox parishes, and this is despite the Peter the Great reform, which reduced the jurisdiction of the church, including it in the state "machine." The vast territory of the Empire was populated by representatives of different faiths (the Charter of foreign confessions), who wanted to certify important facts according to the norms of their confessions, without applying to Orthodox parishes. In the later period of the Russian Empire, the registration of general acts of status (metric records) was assigned to non-Orthodox and non-Christian religious communities recognized by the State. This was especially the case with the Old Believers, who did not recognize Orthodoxy and did not have their own clergy and, accordingly, did not register birth, death and marriage. The Solomon's decision was made: general acts of status were registered by religious communities. In any confessional hierarchy, there was a person responsible for religious rites, for example: orthodox Christians have priests (deacons and acolytes), 
Catholics have vicars, Jews have rabbis, Mohammedans have mullahs, etc. Adherents of sects (unrecognized by the state confessions) had to apply to the authorities for obtaining a metric record.

Despite the fact that the questions of recording in the metric books were made according to religious norms, there was a general approach to the format of the act record. Ministers in Orthodox parishes logged metric (parish) books by the types of general acts of status and the extracts from them called metric certificates were handed to the interested person. However, the metric certificate issued in the parish was not legally valid, it was called a "safety document." To get a fullfledged document, you should contact the consistory. Probably, such an algorithm was designed to eliminate possible biographical and demographic errors in the field, double control gives more confidence.

Metric records certified the legitimacy of birth, age, kinship, marital status, indicating the date and place of marriage, and death. In their content, the metric books were forms, from which even minor deviations were not allowed. Since 1806 it was decided to print copies of metrical books, but since this led to an increase in the cost of fees for act records, church parishes had the opportunity to abandon the practice of such innovations.

The first record in relation to a citizen is a birth certificate, which indicated: the date and place of birth; the date and place of baptism or other religious rite associated with the birth; name; gender; title (estate), full name, including the first name, patronymic and surname, the religion of the father and mother; title (estate), the name of the godparents (for Christians). Godparents, so-called adoptive parents, were often older relatives on the father's or mother's side of the newborn. The society of believers condemned adultery, and in the case of the birth of an illegitimate child by an unmarried woman, information about the father was entered only if he wished. However, such "strict" rules did not apply in all religious communities. It should be noted that there was another discriminatory position of women: the first metric books did not provide for the indication of information about the mother of the child until 1831. According to P.A. Svishchev, the records in the metric books recorded data in territorial, temporal and social coordinate systems, which made them the most valuable informative sources about 
the biographical and demographic information of a person (Svishchev, 2006, p. 7).

The institution of civil status acts underwent a radical diversification during the formation of the Soviet government, which completely excommunicated the church from the management of society, including by secularizing the metric books. As already noted, a new era for the Institute of civil status acts began with the adoption of the Decree of the VTsIK and the SNK dated 18.12.1917 "On civil marriage, on children, and on the logging of civil status records." the creation of a modern model of civil status acts in Russia and the establishment of civil registry offices.

\section{IV. "State Registration of the Act of Civil Status" and "Record of the Act of Civil Status"}

We believe that the terminology "record" of civil status has historically taken root, despite attempts to replace the phrase "state registration." The terms "state registration of the act of civil status" and "record of the act of civil status" are synonymous since the record is a state registration, namely, an administrative act confirming a certain legal fact (birth, marriage or divorce, determination of paternity, adoption, change of name, death), which is called "act of civil status" by law. The primary element of the Unified State Register of Civil Registry Offices is considered to be state registration or record of the act of civil status, to which certain requirements are imposed at the legislative level: formality, reliability, formality, uniformity and relevance. The principles of civil registration are interrelated.

The formality of a civil registration act means that it is made by authorized state bodies within the limits of their competence established by law. State registration of civil status acts refers to the competence of the Russian Federation, which can be transferred to the state authorities of its subjects (with the possibility of delegating to local selfgovernment bodies of municipal districts, urban districts, urban and

${ }^{8}$ Decrees of the Soviet government (1957). Vol. I. October 25, 1917 - March 16, 1918. Moscow, p. 247 (In Russ.). 
rural settlements). ${ }^{9}$ In addition, employees of the civil registry office or a multifunctional center for the provision of state and municipal services are empowered by the current legislation in the field of state registration of acts of civil status (only accepting applications and issuing certificates (extracts from the register)). Outside of the Russian Federation, officials of consulates have the authority in the field of civil registry offices. ${ }^{10}$

The activities of the civil registry offices are indisputable, civil status records are carried out based on submitted official documents in accordance with legal requirements, which presupposes the reliability of the information of the civil registry office. In the absence of the necessary documents or doubts about their authenticity, the recording of the civil status act may be suspended or refused.

\section{Categories "Form" and "Architecture"}

The formality requirement is disclosed through the category "form." The word "form" is polysemantic. Even Plato used it in a different meaning, in the meaning of "idea" to define truly being, which is the expression of individual phenomena. The term "form of recording the act of civil status" is fixed at the legislative level, which, in our opinion, is an external expression of an administrative act, i.e. state registration (record) act of civil status. Although the definition itself is not available in the legislation. We believe that based on the generally accepted ideas about this category the following definition could be given: "the form of the civil status act is an external expression of the structure of the legally established content of the act record, which is applied to paper carriers of the relevant information." We believe that the term "civil

9 Subparagraph 3 of paragraph 1 of article 4 of the Federal Law No 143 -FZ dated November 15, 1997, "On acts of civil status" (as amended on April 24, 2020). Collection of Legislation of the Russian Federation (24.11.1997), No 47, Art. 5340 (In Russ.).

${ }_{10}$ Paragraph 3 of article 4 and article 5 of the Federal Law No 143-FZ dated November 15, 1997, "On acts of civil status" (as amended on April 24, 2020). Collection of Legislation of the Russian Federation (24.11.1997), No 47, Art. 5340 (In Russ.); article 5 of the Federal Law No 154-FZ dated July 5, 2010, "The Consular Charter of the Russian Federation" (as amended on July 26, 2019). Collection of Legislation of the Russian Federation (12.07.2010), No 28, Art. 3554 (In Russ.). 
status act form" used by the legislator is broader in meaning as it means not only the external expression, but also the internal content of the legal category "civil status act." This conclusion is made on the ground of a systematic interpretation of the norms of law in the field of state registration of civil status acts. The legal basis for the form of text recording of civil status acts comprises Federal Law No 143-FZ dated November 15, 1997, "On Civil Status Acts" (as amended on April 24, 2020) ${ }^{11}$ and Order of the Ministry of Justice of the Russian Federation No 202 dated October 01, 2018, "On Approval of Civil Status Record Forms and Rules for Filling out Civil Status Record Forms" (as amended in 2019) (hereinafter referred to as the Order). ${ }^{12}$

The legislative introduction of the digital format of the Unified State Register of Civil Registry Offices does not exclude the obligation to maintain the prescribed form of recording for each type of acts separately, which are collected within a year in chronological order in the books of state registration of acts of civil status (act books), and the issuance of information about the act of civil status on a material carrier, with the provision of an electronic or paper document, as well as certificates of civil status of the established sample (birth, marriage and divorce, death). Civil status records have a unique identification number, the order of assignment of which is regulated by paragraph 17 of the Rules for Maintaining the Unified State Register of Civil Status Records, approved by the Decree of the Government of the Russian Federation No 738 dated June 27, 2018. ${ }^{13}$ All act records on the territory of the Russian Federation are assigned a unique digital identifier. The textual record of a civil status act, depending on its type, has a unique

${ }^{11}$ Federal Law No 143-FZ dated November 15, 1997, "On acts of civil status" (as amended on April 24, 2020). Collection of Legislation of the Russian Federation (24.11.1997), No 47, Art. 5340 (In Russ.).

${ }_{12}$ Order of the Ministry of Justice of the Russian Federation No 202 dated October 1, 2018, "On approval of civil status record forms and rules for filling out civil status record forms" (as amended in 2019). The official internet-portal of legal information. Available at: www.pravo.gov.ru (In Russ.).

${ }_{13}$ Decree of the Government of the Russian Federation No 738 dated June 27, 2018, "On approving Rules for maintaining the Unified State Register of Civil Status Records." Collection of Legislation of the Russian Federation, No 27, Art. 4089 (In Russ.). 
structure, i.e. "architecture." ${ }^{14}$ Let us try to justify the introduction of a new terminology: "architecture of civil status act recording" in connection with the change in the format of maintaining the registry information of the registry office.

Therefore, we believe that the officially used concept of "form of recording the act of civil status" is outdated. Due to the maintenance of an electronic resource and the digitalization of the registry office information, we suggest using the category "architecture of civil status act recording," which is more consistent with the terminology of the ongoing information and technological transformations and their legal regulation. Linguistic and systematic interpretation of the term "architecture" allows us to conclude that it is permissible to apply to the category of "civil status record," defining its internal content and external form at the same time.

We distinguish between the architecture of the text record of civil status acts and its format, which in turn can be physical and digital. Digital format is presented as a structured encoded text information in a convenient form for collecting, processing, storing and transmitting data in an electronic document or electronic document flow with the help of high technologies. The format (from the word "to form") is responsible for the content of the information, while the architecture provides the internal structure and external expression of the content of the information.

Under the architecture of the civil status act record, we propose to understand logically structured information that represents a set of data about a certain life circumstance (event or action), in a strictly prescribed manner, having an external perception. Using the mnemonics of the information system, a text record of the civil status act is entered, which is stored and transmitted in electronic format using XML (eXtensible Markup Language).

In addition, we believe that along with maintaining the electronic Unified State Register of Civil Registry Offices, duplicating civil status records on paper is impractical, since this leads to an irrational use of

${ }_{14}$ The word "architecture" (in Latin "architectura") comes from the Greek words "arkhi" and "teckton" that means "chief" and "creator." 
material and labor resources. At the legislative level it is established that civil status acts both in the form of electronic and paper documents must be identical in content, except for the presence of handwritten signatures on paper of the act record, meanwhile in an electronic document it is mandatory to indicate the codified elements of the corresponding record of the act from sources contained in the federal state information system of the Unified State Register of Civil Registry Offices (paragraph 3 of the Order).

\section{Types of Civil Status Acts}

Regardless of the type of act record, there is a concept of mandatory details in the structure that are present in each civil status record. The cumulative sequence of the details of the act record that make it available for perception comprises the record of civil status acts. The mandatory components include information about a person that records the civil status act, information about the person who applied to the civil registry office (full name, citizenship, date and place of birth, passport data), date and place of recording, type of act record, special (official) marks.

The name of person that performs the state registration of the act of civil status must be indicated in the record of acts (paragraph 20 of the Order). Perhaps this element will be the starting point (the zero element) in the act record.

Contacting the Civil Registry Office is one of the legally significant actions that can be performed personally or through a representative. When applying for State registration of legal facts defined by law as acts of civil status, the applicant ${ }^{15}$ must identify himself by presenting an identity document. Documented identifying information about the person, in respect of which the act record is made, indicating his last name, first name, patronymic and passport data, must be entered (the first element of the civil status record). The obligatory information

${ }_{15}$ The circle of applicants is defined normatively. See the Order of the Ministry of Justice of the Russian Federation No 298 dated December 29, 2017, "On approval of the Administrative Regulations for the provision of public services for state registration of acts of civil status by bodies carrying out state registration of acts of civil status in the territory of the Russian Federation.” Available at: https://www.garant.ru/products/ ipo/prime/doc/71769524/ [Accessed 11.02.2021] (In Russ.). 
includes data about his citizenship (the official name of the state is indicated in the nominative case). Data on "nationality" and "education" are filled in at the request of the applicants. If you do not want to specify this data, a dash is inserted. The requirement of uniformity of the act of civil status consists in a clear and detailed regulation of the writing of its details.

The sections "Service marks" and "Information about corrections and changes made" are elements of the record that may not be filled in. These columns of the act record "indicate the details and date of issue of repeated certificates and certificates issued to citizens, the date of marking the special status of the act record, the details of the document on the basis of which the mark on the special status of the act record is made, as well as other information in accordance with the legislation of the Russian Federation" (paragraph 28 of the Order). We believe that such provisions of the law are aimed at implementing the principle of the relevance of the act record. When making changes or making an official mark in the record of the act in the Unified State Register of Civil Registry Offices, a new version of the record of the act is created in the form of an electronic document, which is signed with an enhanced electronic signature of the head of the person performing state registration of civil status acts (or an employee authorized by him).

Based on the official nature and strict observance of formal requirements, the method and means of recording civil status acts are normatively regulated: only the use of technical means of the Federal State Information System "Unified State Register of Civil Status Records" is allowed. The Order regulates in detail the requirements for the color and font size for entering each requisite of the civil status record. Text records cannot contain hyphenation in words, which is due to the conversion of the test to the digital format of the Unified State Register of Civil Registry Offices. The only exception applies to compound words that contain a hyphen.

The signature of the applicant and the authorized employee of the person carrying out the state registration of civil status acts (indicating the surname and initials) and an imprint of the official seal are considered mandatory components of each record of the act. After making an official record, the applicant (or a person authorized 
by him) may be provided with an extract in the form of an electronic document or issued a certificate of official record of the established model. The electronic document is signed with the enhanced qualified electronic signature of the official of the person performing the state registration of acts of civil status. The certificate of registration is signed by the handwritten signature of the head (authorized person) of the civil registry office and sealed (the seal should not cover the signature and the text of the document).

The final component is the option "Details of the issued certificate," where the series, number and date of the issued certificate are specified.

The digital format of the civil status record is a way of recording information, in which the text is converted into a certain sequence of digital codes. Recording of the civil status act, making changes to it, as well as its cancellation is carried out using the software developed by the operator of the Unified State Register of Civil Registry Offices, i.e. the Federal Tax Service. ${ }^{16}$

\section{Information Security}

Cloud technologies of distributed data processing allow the relevant officials of the civil Registry office to perform the required actions on the platform of the state registration of civil status acts online, having confirmed the legality of access to the information system, to perform the required action on the platform of state registration of acts of civil status. The programs provide possibility to work on the local personal computer of employee of the civil registry office in a web browser, connecting it with a remote Internet server. The term "cloud" in the name of technologies is an allegory in the name, personifying the infrastructure that includes operating systems and software that hide such technical solutions as online services. A single cloud environment has been created on the territory of Russia, which unites all registry offices.

${ }^{16}$ The operator of an electronic resource is the person who ensures the continuous operation of this electronic resource. The law assigns the duties of the operator of the Unified State Register of Civil Registry Offices to the Federal Tax Service of Russia. The administrators of the electronic resource are the officials of the Civil Registry Office, who are responsible for entering records. 
The information security of the act records, including the information of the Unified State Register of Civil Registry Offices, is provided in a comprehensive manner: legally and technically. Threats (so-called "cyberattacks") are possible at all levels: infrastructure, transmission channels, and directly data collection and processing devices (computers of civil registry office employees). Technical security measures add up to monitoring the virtual environment of the registry office, control over the administrator's workplace, the hypervisor (software) and the management server. Software and hardware tools for protecting information with strict two-factor authentication of the ESMART Token GOST smart card, certified by the FSB of Russia, have been developed for help to administrators. Civil registry office officials are connected to the information system and after confirming their access by means of cryptographic protection tools, they can provide state services for registration of acts of civil status online.

Legal measures are aimed at prevention (prophylaxis) and punishing violations of the Internet space of the Civil Registry Office, as well unauthorized access and protection of civil status acts.

\section{Conclusion}

In order to improve the legal regulation in the field of civil registry offices it is proposed as follows:

1) introduce the concept of "architecture of civil status act recording";

2) establish the Unified State Register of Civil Registry Offices as an exclusively electronic resource based on the extraterritorial principle;

3) abolish the maintenance of record books on paper;

4) introduce the format of an electronic document for extracts and certificates issued on the basis of records of the Unified State Register of Civil Registry Office;

5) exempt applicants from the need to present information on paper documents since it can be requested and transmitted over nondepartmental telematics networks;

6) mobilize technical and legal "forces" to ensure the information security of the Unified State Register of Civil Registry Offices. 
We believe that the proposed measures will eventually contribute to the effectiveness of the Registry Office and optimize the maintenance of civil status records in digital format.

\section{References}

1. Antonova, E.E., (2012). Legal regulation of the formation and use of registry information. Cand. Sci. (Law) Diss. Ekaterinburg (In Russ.).

2. Baturin, Yu.M., (1991). Problems of computer law. Moscow (In Russ.).

3. Boyarintseva, O.A., (2019). State and municipal (public) databases as objects of information legal relations. Cand. Sci. (Law) Diss. Moscow (In Russ.).

4. Breckenridge, K. and Szreter, S., (2014). Registration and Recognition: Documenting the Person in World History. British Academy Scholarship Online, doi: 10.5871/bacad/9780197265314.001.00o.

5. Chebotareva, A.A., (2014). Information law. Moscow: Law Institute of MIIT (In Russ.).

6. Gordon, A., (2018). The Paper Parish: The parish register and the reformation of parish memory in early modern London. Memory Studies, 11(1), pp. 51-68, doi: 10.1177/1750698017736838.

7. Hunter, W. and Brill, R., (2016). "Documents, Please" Advances in Social Protection and Birth Certification in the Developing World. World Politics, 68(2), pp. 191-228, doi: 10.1017/So043887115000465.

8. Ivanov, D.V., (2012). Legal regimes of information sources in ensuring information security of the Russian Federation. Cand. Sci. (Law) Diss. Saint Petersburg (In Russ.).

9. Kamalova, G.G., (2020). Legal protection of information confidentiality in the context of the development of a formative society. Dr. Sci. (Law) Diss. Moscow (In Russ.).

10. Khabrieva, T.Ya. and Chernogor, N.N., (2018). Law in the Context of Digital Reality. Journal of Russian Law, (1), pp. 85-102 (In Russ., abstract in Eng.).

11. Khabrieva, T.Ya., (2017). Introduction. In: Shuvalov, I.I., Khabrieva, T.Ya., Tszinzhu Fen et al. Cyberspace of the BRICS: Legal dimension. Monograph. Moscow (In Russ.). 
12. Kopylov, V.A., (1998). On the theoretical problems of the formation of information law. Information resources of Russia. Moscow, 3, pp. 15-21 (In Russ.).

13. Minbaleev, A.V., (2006). System of information: Theoretical and legal analysis. Cand. Sci. (Law) Diss. Chelyabinsk (In Russ.).

14. Minbaleev, A.V., (2012). Theoretical foundations of the legal regulation of mass communications in the context of the development of the information society. Dr. Sci. (Law) Diss. Chelyabinsk (In Russ.).

15. Naumov, V.B., (2018). Law in the era of digital transformation: in search of solutions. Russian Law: Education, Practice, Science, 6, pp. 4-10 (In Russ., abstract in Eng.).

16. Naumov, V.B., (2020). Institute of identification in information law. Dr. Sci. (Law) Diss. Moscow (In Russ.).

17. Polyakova, T.A., (2020). The impact of digital transformation on the development of information law: trends, problems, prospects. Monitoring prvoprimeneniya [Monitoring of law enforcement], 2(35), pp. 53-58 (In Russ., abstract in Eng.).

18. Savenkova, D.D., (2019). Institute of Legal Responsibility in the System of Legal Support of Information Security in the Russian Federation. Cand. Sci. (Law) Diss. Moscow (In Russ.).

19. Shershenevich, G.F., (1995). Russian Civil Law. Moscow: Spark (In Russ.).

20. Svishchev, P.A., (2006). Documentary genealogical sources as an evidence base of genealogical research. Zauralskaya genealogiya: sbornik nauchnyh trudov, 2, pp. 7-15 (In Russ.).

21. Szreter, S., (2007). The Right of Registration: Development, Identity Registration, and Social Security - A Historical Perspective. World Development, 35 (1), pp. 67-86, doi: 10.1016/j.worlddev.2006.09.004.

22. Tereshchenko, L.K., (2011). Legal regime of information. Dr. Sci. (Law) Diss. Moscow (In Russ.).

23. Vengerov, A.B., (1978). Law and information with regard to management automation: Theoretical issues. Moscow: Yuridicheskaya literatura (In Russ.).

24. Zhilkin, V.A., (2018). Digital technologies and the use of artificial intelligence in Finland and Russia: comparative legal research. 
Zhurnal zarubezhnogo zakonodatelstva i sravnitelnogo pravovedeniya [Journal of foreign legislation and comparative law], 6, pp. 74-78, doi: 10.12737/art. 2018.6.5 (In Russ., abstract in Eng.).

\section{Information about the Author}

Irina A. Trofimets, Cand. Sci. (Law), Associate Professor, Embassy of the Russian Federation in the Kingdom of Spain, Madrid, Spain

SPIN-code: 2552-0632

155 calle Velazquez, Madrid 28002, Spain

kosareva-khv@mail.ru 